\title{
PREVALENCE OF ENTEROTOXIN-ENCODING GENES AMONG DIVERSE SHIGELLA STRAINS ISOLATED FROM PATIENTS WITH DIARRHEA, SOUTHWEST IRAN
}

\author{
MoJTABa MoOSAVIAN $^{1,2}$, SAKINEH SEYED-MOHAMmadi ${ }^{2,3}$, \\ AHMAD FARAJZADEH SHEIKH ${ }^{1,2}$, SAEED KHOSHNOOD ${ }^{2,3}$, \\ ARAM ASAREHZADEGAN DEZFULI ${ }^{2}$, MORTEZA SAKI ${ }^{2,3 *}$, \\ GHOLAMrEZA GHADERIAN $^{2}$, FATEMEH SHAHI ${ }^{2,3}$, MAHTAB ABDI ${ }^{2}$ \\ and FARIBA ABBASI ${ }^{4}$ \\ ${ }^{1}$ Infectious and Tropical Diseases Research Center, Health Research Institute, Ahvaz \\ Jundishapur University of Medical Sciences, Ahvaz, Iran \\ ${ }^{2}$ Department of Microbiology, Faculty of Medicine, Ahvaz Jundishapur \\ University of Medical Sciences, Ahvaz, Iran \\ ${ }^{3}$ Student Research Committee, Ahvaz Jundishapur University of Medical Sciences, \\ Ahvaz, Iran \\ ${ }^{4}$ Department of Laboratory Sciences, Golestan Hospital, Ahvaz Jundishapur University of \\ Medical Sciences, Ahvaz, Iran
}

(Received: 27 May 2018; accepted: 22 June 2018)

Shigella spp. are a major cause of bacillary dysentery, particularly among children in developing countries such as Iran. This study aimed to investigate the presence of two important Shigella enterotoxins (ShET-1 and ShET-2), encoded by the set and sen genes, respectively, by polymerase chain reaction (PCR) assay among Shigella species isolated from children affected by shigellosis in Ahvaz, southwest of Iran. In this cross-sectional study, from June 2016 to April 2017, altogether 117 Shigella isolates were collected from fecal specimens of children aged $<15$ years with diarrhea in Ahvaz, southwest Iran. All isolates were identified by standard microbiological and molecular methods. The presence of enterotoxin genes was determined by PCR. The most prevalent isolate was Shigella flexneri (47.9\%), followed by Shigella sonnei (41\%) and Shigella boydii (11.1\%), respectively. Shigella dysenteriae was not detected in patients' samples. The frequencies of $\operatorname{set} 1 \mathrm{~A}, \operatorname{set} 1 \mathrm{~B}$, and sen genes were $5.1 \%(6 / 117), 15.4 \%$ (18/117), and $76.9 \%$ (90/117), respectively. This study provides initial background on the prevalence and distribution of the Shigella enterotoxin genes in Shigella isolates in southwest of Iran. In addition, this study revealed a high prevalence of sen enterotoxin gene in Shigella species.

Keywords: Shigella, diarrhea, Iran, enterotoxin, PCR, sen, set

*Corresponding author; E-mail: saki.mo@ajums.ac.ir 


\section{Introduction}

Shigellosis or bacillary dysentery caused by four Shigella species (Shigella flexneri, Shigella dysenteriae, Shigella boydii, and Shigella sonnei) is known as a main public health problem worldwide especially in low-hygienic regions [1-3]. Shigellosis is identified throughout different spectrum of clinical symptom from mild watery diarrhea to severe colitis. A major group affected by shigellosis are children under 5 years old $[1,4,5]$. Various epidemiological studies revealed that $S$. flexneri 2 a and $S$. sonnei were predominant strains among Shigella spp. in both developing and developed countries [6, 7]. Based on the previous reports worldwide, 164.7 million people are annually infected by Shigella spp., in which 163 million of them are related to developing countries $[8,9]$.

There are different virulence factors in Shigella species. Shigella enterotoxin 1 (ShET1) and Shigella enterotoxin 2 (ShET2) are the two important virulence factors suggested to mediate early fluid secretion in the jejunum and cause of infection in the colon and create watery diarrhea due to shigellosis. The shared name is due to their similar properties as enterotoxins, as there is no homology between ShET1 and ShET2 [10].

ShET1 is encoded by set $1 A$ and set $1 B$ genes located on the Shigella chromosome and it is part of the Shigella Island 1 (SHI-1), and mainly present in $S$. flexneri 2a isolates. The two subunits form a $55 \mathrm{kDa}$ holo-AB-type toxin complex in an A1-B5 configuration. The holotoxin secretion mechanism is similar to that of the cholera holotoxin, via the secretory pathway and type-II secretion. ShET1 is associated with the watery phase of diarrhea $[11,12]$.

Another enterotoxin named ShET2 is encoded by ospD3 (sen), which is one of the three $\operatorname{spp} D$ genes found on the virulence invasion plasmid. This gene is present in all of Shigella serotypes and participates in invasion to host epithelial cells [13].

Khuzestan province in the southwest of Iran is an endemic area for Shigella infections in children [14]. Rapid diagnosis of Shigella strains is an effective way to control and to decrease the rate of shigellosis outbreaks among the children. Since using valid diagnostic techniques like polymerase chain reaction (PCR) is highly recommended [5], the aim of this study was to assess the prevalence of Shigella spp. and the presence of two important ShET-1 and ShET-2 enterotoxin genes by PCR method among Shigella isolates in children affected by shigellosis in Ahvaz, southwest Iran. 


\section{Materials and Methods}

\section{Ethics}

This study was approved by the ethics committee of Ahvaz Jundishapur University of Medical Sciences, Ahvaz, Iran (no.: IR.AJUMS.REC.1396.568).

\section{Study design and specimen collection}

This descriptive and cross-sectional study was conducted on 840 fecal specimens of children under 15 years old suffering from diarrhea during June 2016 and April 2017. All samples were obtained along with written consent from children's parents. These patients were referred to the medical diagnostic laboratories of the teaching hospitals of Abuzar and Golestan associated with the Ahvaz Jundishapur University of Medical Sciences in Ahvaz city, Iran. Patient information, such as age, gender, history of fever, vomiting, and bloody diarrhea, was recorded. Before antibiotics consumption, stool samples of all patients were collected in sterile containers and transferred to the Microbiology Department of Faculty of the Medicine for further investigation.

\section{Isolation and identification of Shigella spp.}

All specimens were cultured on MacConkey and Hektoen enteric (HE) agar (Merck, Germany), and then incubated at $37^{\circ} \mathrm{C}$ for $24 \mathrm{~h}$. Small green to bluish green colonies on HE and colorless colonies on MacConkey agar were selected and examined using standard biochemical and microbiological tests such as Triple Suger Iron agar (Merck, Germany), Lysine Iron agar (Merck, Germany), Simmon's citrate (Merck, Germany), MR-VP, SH2 production, urease, indole production, and motility [15]. All of the isolates confirmed as Shigella spp. were stored at $-80{ }^{\circ} \mathrm{C}$ in tripticase soy broth with $20 \%$ glycerol for further investigations. Shigella species were differentiated by PCR using specific primers.

\section{DNA extraction}

The boiling method was used to extract genomic DNA from Shigella isolates. A few bacterial colonies of Shigella strains grown overnight on nutrient agar (Merck, Germany) were resuspended in microtubes containing $500 \mu \mathrm{l}$ of Tris-EDTA buffer, then the microtubes were placed in Incublock microtube 
incubators (Denville Scientific, USA) for $5 \mathrm{~min}$ at $95{ }^{\circ} \mathrm{C}$, and then centrifuged at $14,000 \mathrm{rpm}$ for $10 \mathrm{~min}$ at $4^{\circ} \mathrm{C}$. The supernatant was used as the DNA template in the PCR assays. The DNA quantity and quality were assessed using NanoDrop Spectrophotometer PROMO (Thermo Scientific, USA) and electrophoresis on $1.5 \%$ gel agarose, respectively [16].

PCR for Shigella spp. differentiation and enterotoxin genes

Differentiation between Shigella spp. was performed by amplification of species-specific genes using primers for putative integrase for Shigella genus, $r f c$ for S. flexneri, wbgZ for S. sonnei, rfpB for $S$. dysenteriae, and hypothetical protein for $S$. boydii as described in previous studies $[17,18]$. Afterward, the existence of Shigella enterotoxins was assessed by amplification of sequences associated with $\operatorname{set} 1 A$, $\operatorname{set} 1 B$, and sen genes according to previous method described by Cruz et al. [7].

PCR assay was performed in thermocycler (Eppendorf, Germany) using the $2 \times$ Master Mix (1.5 $\mathrm{mM} \mathrm{MgCl}_{2}$, SinaClon, Iran). The primers oligonucleotides used in this study were obtained from Pishgam Co. (Iran). The reference strains of S. flexneri ATCC29903, S. sonnei ATCC25931, S. boydii ATCC8700, and $S$. dysenteriae ATCC13313 were used as positive control. The control positive for enterotoxins genes ( $\operatorname{set} 1 A, \operatorname{set} 1 B$, and $s e n)$ was kindly donated by Dr. H. Hosseini Nave of the Department of Microbiology and Virology, School of Medicine, Kerman University of Medical Sciences, Kerman, Iran. The total volume of PCR reaction was $25 \mu \mathrm{l}$ prepared as follows: $12.5 \mu \mathrm{l}$ of $2 \times$ Master Mix, $1 \mu \mathrm{l}$ of $10 \mathrm{pM}$ each primer, $1 \mu \mathrm{l}$ of template DNA, and distilled water to reach total volume of $25 \mu \mathrm{l}$. The cycling program was as follows: 1 cycle at $95^{\circ} \mathrm{C}$ for $5 \mathrm{~min}$, 35 cycles at $954^{\circ} \mathrm{C}$ for $60 \mathrm{~s}$, varying annealing temperatures for each gene for $45 \mathrm{~s}$, and $72{ }^{\circ} \mathrm{C}$ for $45 \mathrm{~s}$, and a final extension cycle at $72{ }^{\circ} \mathrm{C}$ for $5 \mathrm{~min}$. The sterile deionized water was included with each PCR run as negative control. The primers' sequences, annealing temperature, and PCR product size are shown in Table I.

\section{PCR products electrophoresis}

The PCR products were separated by electrophoresis ( $80 \mathrm{~V}, 40 \mathrm{~min})$ using a $1 \%$ agarose gel (SinaClon, Iran) in $1 \times$ Tris/Borate/EDTA buffer. An amount of $5 \mu 1$ from each of the product was run on the agarose gel. Then, the gel was stained with ethidium bromide $(0.5 \mu \mathrm{g} / \mathrm{ml})$ (SinaClon) and visualized by UV illuminator device (ProteinSimple, USA) and all images were saved on hard disk. A DNA marker of $100 \mathrm{bp}$ (Sinaclon) was used for comparative analysis. 
Table I. List of oligonucleotide primers used in PCR method

\begin{tabular}{|c|c|c|c|c|}
\hline Target gene & Primer sequences & $\begin{array}{l}\text { Product } \\
\text { size (bp) }\end{array}$ & $\begin{array}{c}\text { Annealing } \\
\text { temperature } \\
\left({ }^{\circ} \mathrm{C}\right)\end{array}$ & References \\
\hline $\begin{array}{l}\text { Hypothetical } \\
\text { protein }\end{array}$ & $\begin{array}{l}\text { F: GAGCACGGAAACAGAGAGCGCC } \\
\text { R: GGTGCGTTCTTCCGGTGTTCTG }\end{array}$ & 240 & 63 & [17] \\
\hline $\begin{array}{l}\text { Putative } \\
\text { integrase }\end{array}$ & $\begin{array}{l}\text { F: TCGCATTTCTCTCCCCACCACG } \\
\text { R: CCGGATGTGTCTCGGGCAATC }\end{array}$ & 159 & 63 & [17] \\
\hline$w b g Z$ & $\begin{array}{l}\text { F: TCTGAATATGCCCTCTAC } \\
\text { R: GACAGAGCCCGAAGAACCG }\end{array}$ & 430 & 60 & [16] \\
\hline$r f c$ & $\begin{array}{l}\text { F: TTTATGGCTTCTTTGTCG } \\
\text { R: CTGCGTGATCCGACCATG }\end{array}$ & 537 & 60 & [16] \\
\hline $\operatorname{rfp} B$ & $\begin{array}{l}\text { F: TCTCAATAATAGGGAACACAGC } \\
\text { R: CATAAATCACCAGCAAGGTT }\end{array}$ & 211 & 59 & {$[16]$} \\
\hline $\operatorname{set} 1 A$ & $\begin{array}{l}\text { F: TCACGCTACCATCAAAGA } \\
\text { R: TATCCCCCTTTGGTGGTA }\end{array}$ & 309 & 53 & [7] \\
\hline $\operatorname{set} 1 B$ & $\begin{array}{l}\text { F: GTGAACCTGCTGCCGATATC } \\
\text { R: ATTTGTGGATAAAAATGACG }\end{array}$ & 147 & 55 & [7] \\
\hline sen & $\begin{array}{l}\text { F: ATGTGCCTGCTATTATTTAT } \\
\text { R: CATAATAATAAGCGGTCGC }\end{array}$ & 799 & 55 & [7] \\
\hline
\end{tabular}

Note: PCR: polymerase chain reaction.

\section{Results}

In this study, a total number of 117 Shigella species were characterized from 840 fecal specimens by standard biochemical and microbiological tests. These specimens were collected from the children aged $<15$ years old suffering from diarrhea or dysentery during June 2016 and April 2017. Out of 840 cases, 660 $(78.5 \%)$ were children under 10 years old. Considering the gender of patients, 308 $(36.6 \%)$ were females and $532(63.4 \%)$ were males.

For the confirmation of Shigella genus, PCR was carried out using specific primers for putative integrase gene (Figure 1) [17]. The results confirmed the presence of this gene in all 117 isolates. In addition, amplification of speciesspecific genes showed that most isolates belonged to $S$. flexneri $(47.9 \%)$, followed by $S$. sonnei (41\%) and $S$. boydii (11.1\%), respectively (Table II). S. dysenteriae was not detected in any of the samples.

The distributions of the set $1 A$, set1B, and sen genes in studied Shigella spp. are provided in Table II. The frequency of sen gene among 117 Shigella strains was most common with $76.9 \%(90 / 117)$, whereas the set $1 A$ and $\operatorname{set} 1 B$ genes were found only in $6(5.1 \%)$ and $19(16.2 \%)$ isolates, respectively. Among the toxin producers, $17(30.3 \%)$ S. flexneri strains, 4 (8.3\%) S. sonnei, and 4 (30.6\%) $S$. boydii produced ShET-1 (A or B subunit positive), respectively. None of the 


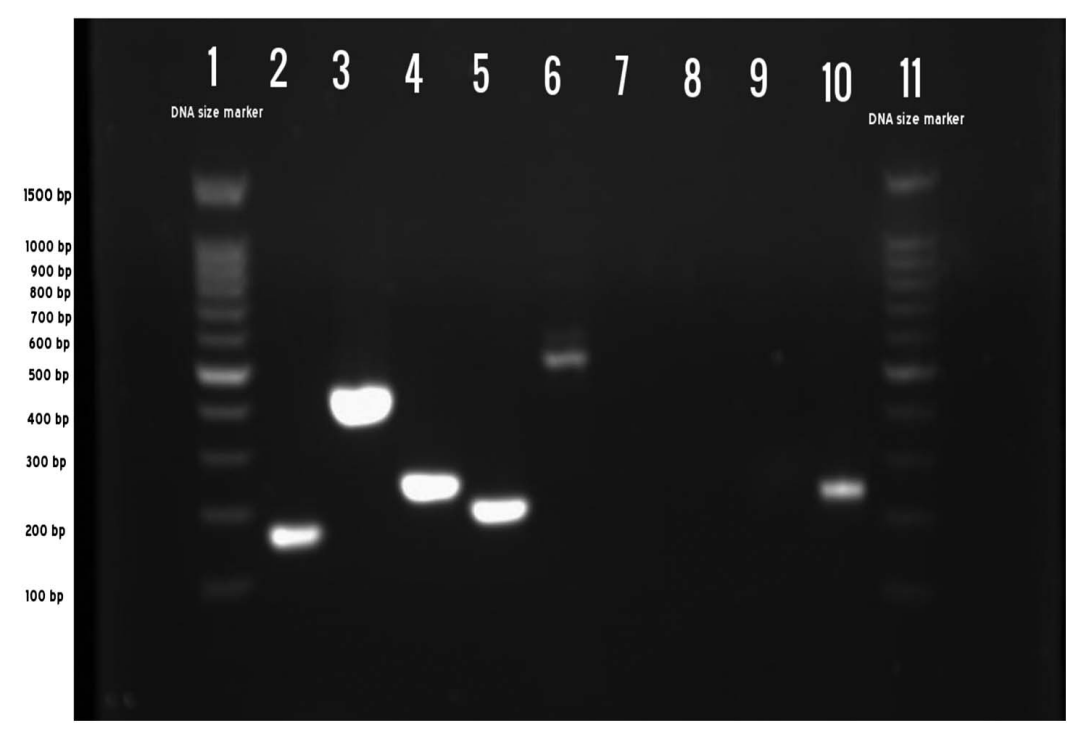

Figure 1. PCR assay profile with Shigella reference strains. Lane 1: 100 bp DNA marker; Lane 2: positive control (putative integrase - Shigella genus); Lane 3: positive control (wbgZ - S. sonnei);

Lane 4: positive control (hypothetical protein $-S$. boydii); Lane 5: positive control ( $r f p B-$

$S$. dysenteriae); Lane 6: positive control ( $r f c-S$. flexneri); Lanes 7-9: negative control; Lane 10: clinical sample (hypothetical protein $-S$. boydii); Lane 11: 100 bp DNA marker

isolates were simultaneously positive for both $\operatorname{set} 1 A$ and $\operatorname{set} 1 B$ genes. Furthermore, the sen gene was detected in $46(82.1 \%)$ S. flexneri, 33 (68.7\%) S. sonnei, and $11(84.6 \%)$ S. boydii. Among the 117 Shigella strains, 20 (17\%) isolates were positive for both the set and the sen genes. Our results show that the prevalence of set1A gene was low in all the Shigella species.

\section{Discussion}

The previous studies have indicated that humans and primates are only natural hosts of Shigella spp. This bacterium with high adaptation with human is a major cause of bacillary dysentery throughout the world, and due to minimal infectious dose (less than 200 bacterial cells), transmission of disease is facilitated in areas with unsuicircumstances such as lack of sanitation [19, 20].

Molecular studies about Shigella enterotoxin genes are still insufficient worldwide and to our knowledge there are no published data on this subject in southwest of Iran. The assessment of Shigella virulence markers helps better understand its pathogenicity. In this study, we investigated Shigella isolates 


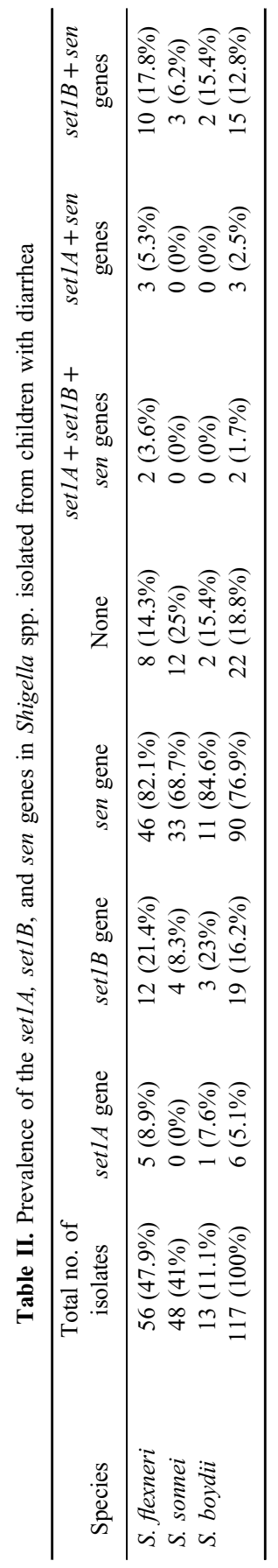


collected from children with diarrhea for the presence of $\operatorname{set} 1 A$, set $1 B$, and sen enterotoxin genes.

Our findings showed that $S$. flexneri (47.9\%) is the most important cause of shigellosis among children in Ahvaz, southwest of Iran. Our results were in accordance with the previous studies in different parts of Iran, such as Babol, Abadan, and some countries like Brazil, China, Egypt, and India [7, 21-24]. In addition, there are some studies that had reported $S$. sonnei as the most prevalent species. These differences may be related to higher hygiene in these regions [25]. In this study, we also assessed the presence of two chromosomal virulence genes (set $1 A$ and $\operatorname{set} 1 B)$ and one plasmid virulence gene (sen) that encode shET1 and shET2, respectively. Both enterotoxins are significantly associated with bloody diarrhea [26].

This study and some studies in recent years are conflict with prior studies that set 1 genes were almost exclusively found in S. flexneri serotypes 2 ( $2 \mathrm{a}$ and $2 \mathrm{~b}$ ) and rarely in other serotypes or species [26-29]. More studies in future may help the confirmation of SHI-1 island as location for set1 gene in different species of Shigella.

We detected set 1 genes in $30.3 \%$ of S. flexneri, $8.3 \%$ of $S$. sonnei, and $30.6 \%$ of $S$. boydii. Ranjbar [5] in Tehran showed that the prevalence of set1 gene was $66.6 \%, 21 \%, 50 \%$, and $0 \%$ in S. flexneri, S. sonnei, S. boydii, and S. dysenteriae, respectively. According to Medeiros's [30] results, $66.7 \%$ of S. flexneri, $11.1 \%$ of S. sonnei, $25 \%$ of $S$. boydii, and $0 \%$ of $S$. dysenteriae carried set 1 genes. In the study by Roy et al. [31] in India, a total of 153 Shigella isolates were analyzed for the presence of set and sen genes. They found set gene only in S. flexneri isolates but not in other species and sen gene was well distributed among all species [31]. In this study, both ShET-1 and ShET-2 were found in $26.7 \%$ of $S$. flexneri isolates. Similarly, Niyogi et al. [27] also reported that $26 \%$ of $S$. flexneri isolates produced both ShET-1 and ShET-2.

Interestingly, most isolates had only one subunit of ShET-1, and B subunit was more frequent than A subunit (Table II). The contingency analysis in Cruz et al.'s [7] study showed that there is a relationship between existence of set $1 B$ gene in Shigella isolates and dehydration symptoms in children. However, answer to the question about whether a single subunit would affect the pathogenicity of ShET-1 needs further study for verification.

In this study, the prevalence of sen gene was higher (78.7\%) than other two genes that was in accordance with reports of the previous studies [12, 30, 32].

The conflict of various researches is likely because of the loss of the large plasmid that contains the gene in different Shigella species, differences in the distribution of species, and the sample size. 


\section{Conclusions}

In this study, we afforded some baseline information about the distribution of some virulence genes in clinical strains of Shigella spp. in Ahvaz city, southwest Iran. We found that the prevalence of sen virulence gene is high among Shigella species in southwest Iran.

\section{Acknowledgements}

The authors would like to thank the children as well as their parents or guardians as they have agreed to participate in this study. This work was financially supported by Deputy Vice-Chancellor for research affair and Infectious and Tropical Diseases Research Center, Health Research Institute, Ahvaz Jundishapur University of Medical Sciences, Ahvaz, Iran (No.: OG-96125). MM and SS-M contributed equally to this work.

\section{Conflict of Interest}

The authors declare no conflict of interest.

\section{References}

1. Ranjbar, R., Dallal, M. M. S., Talebi, M., Pourshafie, M. R.: Increased isolation and characterization of Shigella sonnei obtained from hospitalized children in Tehran, Iran. J Health Popul Nutr 26, 426-430 (2008).

2. Bennish, M. L., Wojtyniak, B. J.: Mortality due to shigellosis: Community and hospital data. Rev Infect Dis 13, S245-S251 (1991).

3. Dekker, J. P., Frank, K. M.: Salmonella, shigella, and yersinia. Clin Lab Med 35, 225-246 (2015).

4. Niyogi, S. K.: Shigellosis. J Microbiol 43, 133-143 (2005).

5. Ranjbar, R., Bolandian, M., Behzadi, P.: Virulotyping of Shigella spp. isolated from pediatric patients in Tehran, Iran. Acta Microbiol Immunol Hung 64, 71-80 (2017).

6. Koppolu, V., Osaka, I., Skredenske, J. M., Kettle, B., Hefty, P. S., Li, J., Egan, S. M.: Small-molecule inhibitor of the Shigella flexneri master virulence regulator VirF. Infect Immun 81, 4220-4231 (2013).

7. Cruz, C. B. N., Souza, M. C. S., Serra, P. T., Santos, I., Balieiro, A., Pieri, F. A., Nogueira, P. A., Orlandi, P. P.: Virulence factors associated with pediatric shigellosis in Brazilian Amazon. Biomed Res Int 2014, ID 539697 (2014). 
8. Wang, Y. W., Watanabe, H., Phung, D. C., Tung, S. K., Lee, Y. S., Terajima, J., Liang, S. Y., Chiou, C. S.: Multilocus variable-number tandem repeat analysis for molecular typing and phylogenetic analysis of Shigella flexneri. BMC Microbiol 9, 278-288 (2009).

9. Li, S., Wang, J., Wei, X., Liu, Y., You, L., Luo, X., Tang, G., Sun, Q., Ye, C., Xu, J., Wang, D.: Molecular characterization of Shigella sonnei: An increasingly prevalent etiologic agent of shigellosis in Guizhou Province, Southwest of China. PLoS One 11, e0156020 (2016).

10. Mattock, E., Blocker, A. J.: How do the virulence factors of Shigella work together to cause disease? Front Cell Infect Microbiol 7, 64 (2017).

11. Fasano, A., Noriega, F. R., Maneval, D. R., Chanasongcram, S., Russell, R., Guandalini, S., Levine, M. M.: Shigella enterotoxin 1: An enterotoxin of Shigella flexneri 2a active in rabbit small intestine in vivo and in vitro. J Clin Invest 95, 2853-2861 (1995).

12. Yavzori, M., Cohen, D., Orr, N.: Prevalence of the genes for Shigella enterotoxins 1 and 2 among clinical isolates of Shigella in Israel. Epidemiol Infect 128, 533-535 (2002).

13. Parsot, C., Ageron, E., Penno, C., Mavris, M., Jamoussi, K., D’Hauteville, H., Sansonetti, P., Demers, B.: A secreted anti-activator, OspD1, and its chaperone, Spa15, are involved in the control of transcription by the type III secretion apparatus activity in Shigella flexneri. Mol Microbiol 56, 1627-1635 (2005).

14. Pour, M. B. M. G., Shokoohizadeh, L., Navab-Akbar, F. T.: Analysis of clonal relationships among Shigella spp. isolated from children with shigellosis in Ahvaz, Iran. J Paramed Sci 7, 45-51 (2016).

15. Tille, P.: Bailey \& Scott's Diagnostic Microbiology-E-Book. Elsevier Health Sciences, St. Louis, MO, 307-327 2015.

16. Li, S., Sun, Q., Wei, X., Klena, J. D., Wang, J., Liu, Y., Tian, K., Luo, X., Ye, C., Xu, J., Wang, D., Tang, G.: Genetic characterization of Shigella flexneri isolates in Guizhou Province, China. PLoS One 10, e0116708 (2015).

17. Ojha, S. C., Yean, Y. C., Ismail, A., Banga, S. K. K.: A pentaplex PCR assay for the detection and differentiation of Shigella species. BioMed Res Int 2013, ID412370 (2013).

18. Kim, H. J., Ryu, J. O., Song, J. Y., Kim, H. Y.: Multiplex polymerase chain reaction for identification of shigellae and four Shigella species using novel genetic markers screened by comparative genomics. Foodborne Pathog Dis 14, 400-406 (2017).

19. Trevett, A. F., Carter, R. C., Tyrrel, S. F.: The importance of domestic water quality management in the context of faecal-oral disease transmission. J Water Health 3, 259-270 (2005).

20. Hossain, M. A., Albert, M. J., Hasan, K. Z.: Epidemiology of shigellosis in Teknaf, a coastal area of Bangladesh: A 10-year survey. Epidemiol Infect 105, 41-49 (1990).

21. Savadkoohi, R. B., Ahmadpour-Kacho, M.: Prevalence of Shigella species and their antimicrobial resistance patterns at Amirkola Children Hospital, North of Iran. Iran J Pediatr 17, 118-122 (2007).

22. Jomezadeh, N., Babamoradi, S., Kalantar, E., Javaherizadeh, H.: Isolation and antibiotic susceptibility of Shigella species from stool samples among hospitalized children in Abadan, Iran. Gastroenterol Hepatol Bed Bench 7, 218-223 (2014).

23. Sangeetha, A., Parija, S. C., Mandal, J., Krishnamurthy, S.: Clinical and microbiological profiles of shigellosis in children. J Health Popul Nutr 32, 580-586 (2014).

24. Ranjbar, R., Afshar, D., Tavana, A. M., Najafi, A., Pourali, F., Safiri, Z., Sorouri Zanjani, R., Jonaidi Jafari, N.: Development of multiplex PCR for simultaneous detection of three pathogenic Shigella species. Iran J Public Health 43, 1657-1663 (2014). 
25. Mardaneh, J., Abbaspoor, S., Afrugh, P.: Prevalence of Shigella species and antimicrobial resistance patterns of isolated strains from infected pediatrics in Tehran. Int J Enteric Pathog 1, 28-31 (2013).

26. Yaghoubi, S., Ranjbar, R., Dallal, M. M. S., Fard, S. Y., Shirazi, M. H., Mahmoudi, M.: Profiling of virulence-associated factors in Shigella species isolated from acute pediatric diarrheal samples in Tehran, Iran. Osong Public Health Res Perspect 8, 220-226 (2017).

27. Niyogi, S., Vargas, M., Vila, J.: Prevalence of the sat, set and sen genes among diverse serotypes of Shigella flexneri strains isolated from patients with acute diarrhoea. Clin Microbiol Infect 10, 574-576 (2004).

28. Cristea, D., Oprea, M., Ciontea, A. S., Antohe, F., Usein, C. R.: Prevalence of virulence markers and pHS-2-like plasmids among Shigella sonnei and Shigella flexneri isolates originating from shigellosis cases in Romania. Rev Romana Med Lab 24, 103-110 (2016).

29. Sousa, M. Â. B., Mendes, E. N., Collares, G. B., Péret-Filho, L. A., Penna, F. J., Magalhães, P. P.: Shigella in Brazilian children with acute diarrhoea: Prevalence, antimicrobial resistance and virulence genes. Mem Inst Oswaldo Cruz 108, 30-35 (2013).

30. Medeiros, P. H. Q. S., Lima, A. Â. M., Guedes, M. M., Havt, A., Bona, M. D., Rey, L. C., Soares, A. M., Guerrant, R. L., Weigl, B. H., Lima, I. F. N.: Molecular characterization of virulence and antimicrobial resistance profile of Shigella species isolated from children with moderate to severe diarrhea in northeastern Brazil. Diagn Microbiol Infect Dis 90, 198-205 (2018).

31. Roy, S., Thanasekaran, K., Roy, A. R. D., Sehga, S. C.: Distribution of Shigella enterotoxin genes and secreted autotransporter toxin gene among diverse species and serotypes of Shigella isolated from Andaman Islands, India. Trop Med Int Health 2, 1694-1698 (2006).

32. Farfán, M., Garay, T., Prado, C., Filliol, I., Ulloa, M., Toro, C.: A new multiplex PCR for differential identification of Shigella flexneri and Shigella sonnei and detection of Shigella virulence determinants. Epidemiol Infect 138, 525-533 (2010). 